\title{
PERANAN FOTO UDARA DALAM PERENCANAAN KOTA
}

\author{
Oleh: Sugiharto Budi S.
}

\begin{abstract}
The aim of this paper is to discuss about the role of aerial pbotograpb in urban planning. According to Nortbam (1979), there are seven elements of urban planning, i.e. (1) population studies, (2) bousing studies, (3) economis studies, (4) lan. duse studies, (5) transportation studies, (6) open space and recreational facilities, and (7) government and public facilities.

There are several variables of each element of urban planning can not be detected on aerial photograph. Nevertheless, aerial photograph bas important role in urban planning, i.e. to get the data, to detect the change, dan to analyze the change, because aerial photograph present the shape and the location of the object similar to the shape and the location on the earth surface.
\end{abstract}

\section{INTISARI}

Tulisan ini bertujuan membicarakan pernanan foto udara dalam perencanaan kota. Menurut Nortbam (1979) ada tujub elemen dalam perencanaan kota, yakni: (1) studi kependudukan, (2) studi perumahan, (3) studi ekonomi, (4) studi penggunaan laban, (5) studi transportasi, (6) perencanaan ruang terbuka dan tempat rekreasi, dan (7) fasilitas pemerintab dan fasilitas umum.

Ada bebarapa variabel dalam setiap elemen perencanaan kota yang tidak dapat disadap dari foto udara. Namun demikian foto udara sangat membantu dalam perolehan data, deteksi perubaban dan analisis perubabannya, karena foto udara menyajikan bentuk dan lokasi obyek yang mirip dengan bentuk dan lokasinya di permukaan bumi.

\section{Pendahuluan}

Kota merupakan kegiatan penduduk yang meliputi kegiatan usaha, jasa, tempat tinggal dan rekreasi dan kegiatan pemerintahan. Sebagai pusat kegiatan maka kota mengalami perkembang. an yang sedemikian pesatnya. Perkembangan ini tidak saja pertambahan pusat-pusat kegiatan tetapi juga pertambahan jumlah penduduknya. Setiap tahun berjuta-juta orang pindah dari desa ke kota. Tingginya pertumbuhan penduduk di daerah perkotaan dalam kurun waktu 1920-1980 menyebabkan jumlah penduduk perkotaan berkembang 11 kali lipat, yaitu dari 2,8 juta menjadi 33 juta jiwa. Memasuki dasa warsa 90-an penduduk Indonesia yang tinggal di wilayah perkotaan sudah mencapai 26\%. Gejala urban spraw! (penjarahan wilayah terbangun hingga melewati batas administrasi kota) dan konurbasi (penyatuan beberapa kota) adalah sebagai akibat tingginya pertumbuhan penduduk kota. Dalam kurun waktu 1980-1985 luas wilayah perkotaan di Indonesia bertambah sebesar 370.000 Ha. (Surna T. Jayaningrat, 1980) 
Pembangunan perkotaan yang begitu pesatnya akan mempengaruhi keadaan lingkungannya. Di sana sini dijumpai bemunculan gedung-gedung yang dibangun pada lahan kota yang kurang tepat. Penggunaan lahan kota yang kurang tepat akan menimbulkan beberapa masalah lingkungan seperti banjir, kebisingan dan kemacetan lalu lintas. Untuk mengatasi hal tersebut perlu adanya perencanaan penggunaan lahan yang matang, dalam arti sudah dipersiapkan sebelumnya. Namun pada kenyataannya, perencanaan penggunaan lahan yang ada saat ini sering kurang cepat bila dibanding dengan penggunaan lahan kota itu sendiri. Hal ini disebabkan oleh (1) pengukuran terestrial di kota sulit dilakukan karena terhalang oleh keramaian lalu lintas dan bangunan yang padat, (2) petugas pemetaan yang terbatas jumlahnya.

Untuk menyediakan data penggunaan lahan kota yang paling mutakhir, apabila dilakukan dengan survei lapangan akan memakan waktu yang cukup lama, jumlah tenaga pemetaan yang banyak, serta beaya yang sangat mahal. Hal ini akan terasa sekali bagi negara yang wilayahnya luas seperti Indonesia. Salah satu cara untuk mengatasi kendala tersebut adalah dengan memanfaatkan data hasil teknologi penginderaan jauh.

Data penginderaan jauh dapat berupa data citra maupun data non citra. Dalam perbincangan ini dibatasi pada data citra yang berupa foto udara. Foto udara dapat menyampaikan informasi obyek perkotaan yang sesuai dengan keadaannya di medan. Semua obyek yang tampak, dalam arti obyek yang ukurannya tidak terlalu kecil dan tidak terlindung oleh obyek lain akan tergambar pada foto udara. Kemampuan- nya yang dapa: meliput daerah luas secara cepat uga merupakan keistimewaannya. Jari foto udara temporal dapat diketahui perubahan pengguna. an lahan kota, dan dapat pula diketahui arah perubahannya. Hal ini sangat penting untuk digunakan sebagai bahan masukan dalam perencanaan kota.

\section{Perencanaan Kota}

Perencanaan kota dapat didefinisikan sebagai perencanaan masyarakat yang hidup di dalamnya maupun lingkungannya untuk menciptakan situasi saat mendatang yang diinginkan (Northam, 1979).

Dari definisi tersebut tampak bahwa perencanaan kota tidak saja perencanaan fisiknya tetapi juga perencanaan manusianya. Menurut Anthony J. Catanese (1984) bahwa perencanaan fisik kota bukanlah satu-satunya kegiatan dasar dalam perencanaan kota. Da. lam perencanaan kota tidak terlepas juga dengan masalah-masalah sosial, ekonomi, lingkungan dan politik yang mempengaruhi kehidupan kota. Perencanaan ekonomi keuangan dan sosial sama pentingnya dengan perencanaan fisik.

Di dalam perencanaan kota banyak sekali dijumpai kendala-kendala, seperti tidak sinkronnya antara perencanaan dengan pelaksanaannya. Hal ini disebabkan proses penyusunan rencana yang memakan waktu terlalu lama, sehingga data-data yang digunakan dalam penyusunan semula sudah tidak sesuai lagi dengan kenyataan sebenarnya di lapangan.

Melihat pertumbuhan kota-kota yang sangat pesat dan sering tak terkendali, rencana Induk Kota (Master Plan) merupakan salah satu alat yang dapat digunakan untuk mengendalikan 
dan mengatur perkembangan yang liar (Herlianto, 1986). Masalahnya sekarang, bagaimana menyediakan Rencana Induk Kota yang benar-benar siap pakai. Disinilah peran data penginderaan jauh sangat diperlukan, seperti yang dikatakan oleh Sutanto (1982) bahwa kegunaan citra tidak akan ada artinya apabila tidak ada faktor-faktor yang mendorongnya. Faktor-faktor yang mendorong ini antara lain: (1) kota merupakan perujudan yang paling cepat mengalami perubahan, sehingga petugas kota sering terlambat'menyajikan data yang paling mutakhir, (2) adanya kepadatan dan ketinggian bangunan serta keramaian lalu lintas, sehingga pengukuran terestrial sering terhambat, (3) citra dapat dibuat secara cepat. Perekaman satu lembar foto udara yang meliput daerah seluas $132 \mathrm{~km} 2$ dilakukan kurang dari satu detik, (4) citra menggambarkan obyek sesuai dengan ujud dan letaknya di medan, (5) citra dapat digunakan sebagai alat kontrol terhadap kesalahan atau subyektifitas petugas lapangan.

\section{Elemen Perencanaan Kota}

Northam (1979) mengutarakan tujuh elemen perencanaan kota, yaitu:

\section{Studi Kependudukan}

Studi kependudukan diperlukan dalam perencanaan, baik untuk mengetahui kondisi penduduk saat ini maupun untuk membuat proyeksi penduduk yang akan datang. Untuk studi ini diperlukan pembedaan penduduk atas dasar umur, jenis kelamin, pendapatan atau kriteria penting lainnya. Disamping itu, studi ini juga harus mempertimbangkan faktor migrasi dan tidak hanya mempertimbangkan pertambahan penduduk secara alami.
Studi kependudukan dalam kaitannya dengan perencanaan kota antara lain untuk memperkirakan jumlah lapangan kerja, jumlah fasilitas kesehatan, fasilitas pendidikan, fasilitas perumahan, pusat perbelanjaan dan fasilitas hiburan.

\section{Studi Perumahan}

Studi perumahan erat kaitannya dengan studi penduduk. Jumlah penduduk saat ini digunakan sebagai dasar untuk perkiraan jumlah rumah saat mendatang. Ditambahkan pula, bahwa studi perumahan juga harus memperkirakan kebutuhan jumlah rumah dengan berbagai tipe (untuk satu keluarga, banyak keiuarga) dengan berbagai harga serta lokasinya. Disamping itu studi ini juga meliputi studi perumahan bagi masyarakat berpenghasilan rendah yang menyangkut kemungkinan dapat dikerjakan, kebutuhannya, tipenya, lokasinya dan waktu yang dibutuhkan.

\section{Studi Ekonomi}

Studi ini meliputi aspek-aspek struktur ekonomi kota, arah pengembangan ekonomi, dan basis ekonomi kota. Basis ekonomi kota diperlukan untuk mengetahui ekonomi kota kaitannya dengan lingkup regional dan nasional. Studi ini juga meliputi inventarisasi angkatan kerja. dan pengembangan proyeksi dari bagian-bagian angkatan kerja tersebut.

\section{Studi Penggunaan Lahan}

Studi penggunaan lahan merupakan elemen terpenting dalam setiap perencanaan kota, karena semua penduduk dan aktifitasnya menempati ruang kota. Inventarisasi penggunaan lahan saat ini sangat penting bagi pembangunan kota 
yang didasarkan pada kelas- kelas kecocokan lahan. Studi ini juga mengkaji kecenderungan penggunaan lahan kota, kepadatan penggunaan lahan, dan kemampuan penyerapan lahan untuk memperkirakan kebutuhan lahan di masa mendatang dengan lebih baik. Monitoring penggunaan lahan perlu dilakukan untuk menghindari adanya gangguan-gangguan, konflik-konflik dan situasi-situasi yang tidak sesuai dengan perencanaan.

\section{Studi Transportasi}

Studi ini menekankan pada studi untuk pengembangan, perencanaan dan administrasi jaringan transportasi, yang terdiri baik fasilitas umum maupun fasilitas khusus, serta pekerjaanpekerjaan yang berkaitan dengan jaringan transportasi. Perencanaan jalan dan jalan raya merupakan bagian dalam perencanaan, yang juga meliputi perencanaan fasilitas lapangan terbang, perencanaan stasiun kereta api dan terminal bus. Pekerjaan yang terkait dalam perencanaan ini adalah fasilitas parkir (di permukaan, di atas dan di bawah tanah), dan fasilitas transportasi untuk kendaraan tak bermotor.

\section{Perencanaan Ruang Terbuka dan \\ Rekreasi}

Elemen ini meliputi perencanaan fasilitas rekreasi di luar bangunan, dan ruang terbuka yang berfungsi sebagai tempat rekreasi. Perencanaan ini juga mencakup tingkat operasi, lokasi dan tipe-tipe daerah rekreasi yang dikehendaki, serta tipe ruang terbuka tertentu untuk keperluan rekreasi, tempat tinggal atau pertanian.

7. Fasilitas Pemerintahan dan Fasilitas Umum
Perencanaan kota bertujuan untuk memenuhi kebutuhan pemerintah dan masyarakat. Banyak ragam fasilitas yang harus terkait dalam perencanaan kota, dengan mempertimbangkan tingkat operasi, tipe fasilitas, waktu pembangunan dan lokasi dari fasilitas. Fasilitas-fasilitas ini meliputi fasilitas sekolah, kesehatan, struktur administrasi, perpustakaan-perpustakaan, stasiun pemadam kebakaran, kantor polisi, dan sistem air dan lain-lain.

\section{Peranan Foto Udara Dalam Perenca- naan Kota}

Seperti yang dikemukakan oleh Northam (1979) bahwa ada tujuh elemen perencanaan kota, yakni: studi kependudukan, studi perumahan, studi ekonomi, studi penggunaan lahan, studi transportasi, perencanaan ruang terbuka dan rekreasi, fasilitas pemerintah dan fasilitas umum. Oleh karena itu bahasan peranan foto udara dalam perencanaan kota juga didasarkan pada ketujuh elemen tersebut.

\section{Kependudukan}

Untuk mengetahui data penduduk diperoleh dengan cara sensus. Cara ini memerlukan waktu relatif lama serta jumlah tenaga pencacah yang cukup banyak pula. Dengan foto udara data jumlah penduduk dapat diperkirakan. Waktu pelaksanaannya jauh lebih cepat serta jumlah tenaga penafsir yang jauh lebih sedikit. Hal ini sangat membantu sekali dalam perencanaan kota. Disamping itu foto udara juga dapat digunakan untuk mengetahui distribusi penduduk, pembuatan peta wilayah sensus, serta penaksiran pertambahan jumlah penduduk.

Namun demikian, tidak semua variabel kependudukan dapat diidentifi- 
kasi dari foto udara. Variabel-variabel tersebut misalnya komposisi penduduk berdasarkan umur, jenis kelamin dan tingkat pendidikan.

Penaksiran jumlah penduduk dapat dilakukan dengan tiga cara (lihat gambar)

model penafsiran

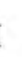

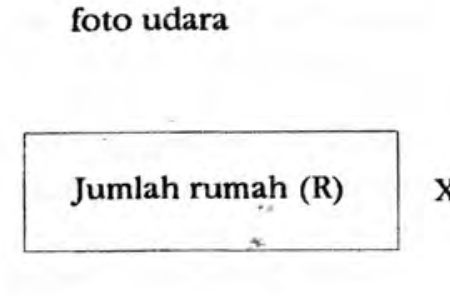

I

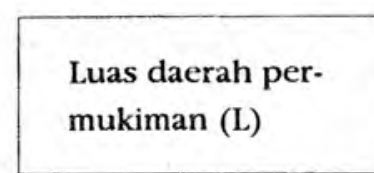

III

Jumlah keluarga yg ditaksir berdasarkan ukuran dan ci-

$\mathrm{X}$
$\mathrm{X}$

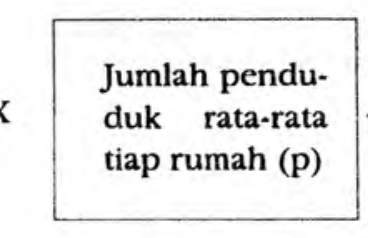

pencacahan pada daerah sampel

hasil

\begin{tabular}{ll|}
\hline & $\begin{array}{l}\text { Kepadatan } \\
\text { penduduk } \\
\text { rata-rata (k) }\end{array}$ \\
\hline
\end{tabular}

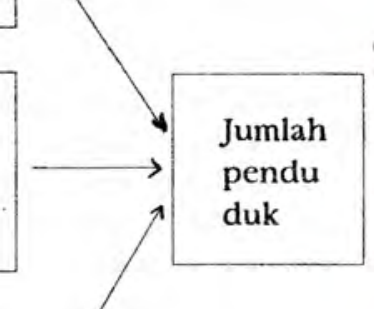
ri rumah $(\mathrm{K})$

Jumlah pendu-

duk rata-rata

tiap rumah (t)

Gambar Model Pendekatan Untuk Penaksiran Jumlah Penduduk (Sutanto, 1982)

Sutanto (1971) melakukan penaksiran jumlah penduduk desa Resquert dan Baflo di Groningen, Nederland, Belanda dengan menggunakan foto udara skala 1:15.000. Jumlah penduduk diperoleh dengan mengalikan jumlah keluarga dengan jumlah penduduk rata-rata yang diambil dari data registrasi (Model III). Dari hasil penelitiannya dapat dibedakan atas rumah yang dihuni oleh satu keluarga, dua keluarga, atau lebih. Pembedaannya didasarkan atas bentuk dan ukuran rumah, jumlah jalan masuk ke halaman, jumlah cerobong asap. Ketelitian hasilnya sebesar $98,6 \%$ terhadap data registrasi.

Pada tahun 1982 ia juga melakukan penelitian serupa di Kecamatan Kalianda dan Kecamatan Palas, Kabupaten Lampung selatan. Bahan yang digunakan foto udara skala 1:20.000, 1:50.000, dan 1:100.000. Penaksiran jumlah penduduknya dengan menggunakan model I dan II yang telah dimodifikasi. Hasil taksirannya mengalami penyimpangan berkisar dari $4,51 \%$ hingga 9,16\%. Taksiran ini lebih teliti bila dibandingkan dengan data registrasi desa daerah penelitiannya, yang 
penyimpangannya terhadap hasil pencacahan lengkap sebesar 9,47\% hingga 49,7\%.

Distribusi penduduk juga dapat diidentifikasi melalui foto udara. Distribusi tercermin oleh distribusi daerah permukiman. Daerah permukiman tampak jelas pada foto udara. Demikian juga faktor-faktor yang mempengaruhi distribusi penduduk seperti topografi, tanah, ketersediaan air juga dapat diidentifikasi melalui foto udara.

Penaksiran pertambahan jumlah penduduk didasarkan pada foto udara seri. Identifikasinya dilakukan dengan menyidik pertambahan jumlah rumah, perluasan daerah permukiman dan perluasan lahan garapan.

\section{Perumahan}

Pada foto udara skala 1:10.000 atau lebih besar, bangunan untuk rumah mukim mudah dibedakan dengan bangunan bukan rumah mukim. Pembedaannya didasarkan pada bentuk, pola, ukuran dan keterkaitannya dengan obyek sekitarnya. Dengan demikian melalui penafsiran foto udara dapat dilakukan penaksiran jumlah rumah, kepadatan perumahan. Disamping itu, foto udara juga dapat digunakan untuk menilai kualitas perumahan, identifikasi daerah permukiman kumuh. Tetapi untuk membuat batas hak milik secara tepat melalui foto udara sangat sulit.

Kepadatan perumahan dibuat dengan membandingkan luas atas perumahan dengan luas daerah permukiman. Data kepadatan perumahan meru. pakan kriteria penting dalam menilai kualitas perumahan (Metivier dan Mc Coy, 1971 dalam Sutanto, 1982)

Ada beberapa variabel untuk menilai kualitas perumahan. Menurut Horton (19 4) (dalam Sutanto 1989) ada tujuh variabel untuk menilai kualitas perumahan melalui foto udara, yakni: (1) adanya tempat parkir, (2) kemacetan oleh bongkar muat, (3) lebar jalan, (4) kemacetan lalu lintas, (5) sampah, (6) kelas jalan, (7) jalan masuk ke rumah.

Ketujuh variabel ini dapat diinterpretasi pada foto udara. Hasil penelitiannya menunjukkan bahwa ada kesamaan antara data dari foto udara dengan data hasil survei lapangan yakni sebesar $82,2 \%$.

\section{Ekonomi}

Data sosial dan ekonomi tidak dapat diidentifikasi secara langsung dari foto udara. Namun demikian perujudan yang tampak pada foto udara sering mencerminkan keadaan sosial dan ekonomi secara tak langsung. Ekonomi kota antara lain tercermin dari jumlah lokasi dan konsentrasi penggunaan lahan komersial (Sutanto, 1982)

Salah satu terapan foto udara untuk studi ekonomi kota adalah untuk identifikasi obyek pajak bumi dan bangunan (PBB).

Obyek Pajak Bumi dan Bangunan berupa obyek tak bergerak, sehingga mudah diamati dan dikenali. Pengamatan obyek ini akan rinci bila diamati satu per satu di lapangan. Tetapi cara ini kurang efisien bila obyek yang diamati cukup banyak dan tersebar. Disamping itu untuk pendataannya diperlukan waktu yang cukup lama. Melalui interpretasi foto udara obyek PBB dapat diidentifikasi secara cepat dengan sedikit kerja medan.

Obyek PBB diidentifikasi melalui foto udara yang dilacak dari kenampakan fisiknya yang berupa jenis penggunaan lahannya. Selanjutnya, obyek ini dikelompokkan berdasarkan status pengenaan pajak. Kelompok tersebut ialah: (1) penggunaan lahan kena pajak (untuk usaha dan non usaha) misal pe- 
mukiman penduduk, pertokoan, (2) penggunaan lahan bebas pajak (yakni untuk kegiatan sosial) misal, musim, tempat ibadah dan (3) penggunaan lahan khusus yakni milik pemerintah.

Status obyek (milik pemerintah, swasta) yang digunakan sebagai dasar pengelompokan obyek sulit diidentifikasi dari foto udara, tetapi harus dilakukan survei lapangan. Sebagai contoh sekolah, sekolah swasta kena pajak, sedang sekolah negeri tidak kena pajak. Namun demikian ada obyek penggunaan lahan yang statusnya dapat diidentifikasi dari foto udara, misalnya stasiun sampai saat ini belum ada stasiun swasta. Pasar sampai sekarang belum ada pasar milik swasta. Sehingga obyek dapat dikelompokkan menjadi obyek bebas pajak (Birowo BS, 1987)

Untuk menentukan besarnya pajak dilakukan dengan mengkalikan luas obyek dengan Nilai Jual Kena Pajak (NJKP) yang ditetapkan pemerintah. Batas persil obyek dapat diidentifikasi dari foto udara skala 1:1.000 yang telah direktifikasi.

\section{Penggunaan Lahan}

Penggunaan lahan merupakan faktor terpenting dalam perencanaan kota. Herlianto (1986) menegaskan bahwa pada dasarnya perencanaan kota tidak lain adalah perencanaan peruntukan lahan (landuse planning).

Seperti dijelaskan pada bab pendahuluan bahwa dalam setiap perencanaan penggunaan lahan kota, kendala utamanya adalah tidak tersedianya data penggunaan lahan pada saat dibutuhkan. Dengan bantuan foto udara kendala ini dapat diatasi karena foto udara menyajikan obyek perkotaan relatif lengkap, meliputi daerah luas, dan untuk pemotretan satu lembar foto udara seluas $132 \mathrm{~km} 2$ dilakukan dalam waktu kurang dari satu detik (Sutanto, 1986).
Dalam perencanaan penggunaan lahan ada fase-fase yang perlu dilakukan. Paine (1981) mengemukakan lima fasefase perencanaan penggunaan lahan, yaitu (1) pemetaan, (2) inventarisasi dan analisis, (3) analisis dan perencanaan, (4) komunikasi ide, dan (5) monitoring perubahan penggunaan lahan. Menurutnya, penggunaan foto udara dan penggunaan citra penginderaan jauh lainnya merupakan alat yang sangat penting pada kelima fase tersebut. Ia menambahkan bahwa penggunaan citra penginderaan jauh merupakan alat yang tidak dapat ditinggal dalam proses inventarisasi dan analisis.

Hal yang perlu diperhatikan dalam perencanaan penggunaan lahan kota adalah faktor skala. Obyek perkotaan yang begitu rumit sulit diidentifikasi secara individual dengan foto skala kecil. Untuk identifikasi obyek perkotaan diperlukan foto udara skala besar, yaitu skala 1:5.000 atau lebih besar untuk pusat kota dan skala 1:6.000 hingga skala 1:15.000 untuk seluruh kota (Sutanto, 1982).

\section{Transportasi}

Perencanaan transportasi sangat penting artinya dalam perencanaan kota. Jaringan jalan serta kualitasnya dan pengaturannya sangat berpengaruh pada kelancaran dan ketertiban arus gerakan manusia dan barang (Sutanto, 1982)

Foto udara telah lama digunakan untuk studi transportasi EC. Barret dan L.F. Curtis (1982) mencontohkan, di USA hampir tiga perempat dari seluruh pekerjaan perencanaan jalan raya menggunakan foto udara. Pekerjaan ini meliputi:

(1) Perencanaan jalan. Dalam perencanaan jalan analisis fotogrametris telah dilakukan baik secara kualitatif maupun secara kuantitatif. 
(2) Studi lalu lintas. Dalam studi ini foto udara dapat menunjukkan dengan tepat lokasi dan sebab-sebab kemacetan. Disamping itu foto udara juga menyajikan informasi arus kendaraan.

(3) Perencanaan tempat parkir. Foto udara dapat menunjukkan dimana terjadi konsentrasi kendaraan. Informasi ini digunakan untuk perencanaan tempat-tempat parkir.

(4) Pemeriksaan jalan raya. Foto udara dapat menujukkan lokasi permukaan jalan yang perlu diperbaiki dengan segera.

\section{Perencanaan Ruang Terbuka dan} Tempat Rekreasi

Dalam setiap perencanaan penggunaan lahan harus diperhitungan tetap adanya ruang terbuka dan tempat rekreasi yang memadai (Sutanto, 1982). Foto udara menyajikan dengan jelas tentang penyebaran, letak dan jumlah ruang terbuka.

\section{Fasilitas Pemerintah dan Fasilitas Umum}

Seperti dijelaskan di muka bahwa udara menyajikan gambaran obyek perkotaan sesuai dengan ujud dan letaknya di medan, maka foto udara sangat membantu dalam penentuan lokasi baru baik untuk fasilitas pemerintah maupun untuk fasilitas umum.

\section{Kesimpulan}

Berdasarkan uraian di atas dapat disimpulkan bahwa

1. Kendala utama dalam setiap perencanaan penggunaan lahan kota adalah tidak tersedianya data penggunaan lahan kota yang paling mutakhir. Hambatan ini dapat diatasi dengan bantuan foto udara, karena foto udara menyajikan informasi tentang obyek perkotaan relatif lengkap.

2. Foto udara menyajikan data obyek perkotaan secara spasial. Dengan demikian foto udara sangat bermanfaat untuk analisis kekuarangan.

3. Karena kota merupakan pusat pelbagai kegiatan, kota sering mengalami perubahan. Perubahan ini terwujud dalam bentuk perubahan penggunaan lahannya. Foto udara dapat menyajikan perubahan bentuk penggunaan lahan kota dan arah perubahannya.

4. Tidak semua informasi elemen perencanaan kota dapat diidentifikasi melalui foto udara. Namun demikian dengan bantuan foto udara pekerjaan lapangan dapat dikurang dan dipercepat.

\section{Daftar Pustaka}

Anthony J. Catanese dan James C. Snyder 1984. Pengantar Perencanaan Kota. Jakarta: Erlangga.

Birowo Budi Santosa. 1987. Penggunaan Foto Udara Pemetaan Obyek Pajak Bumi dan Bangunan di Kotamadya Yogyakarta. Skripsi Sarjana Fakultas Geografi UGM.

David P. Paine 1981. Aerial Photography and Image Interpretation for Resource Management. New York: John Wiley and Sons Inc. 
EC. Barrett and L.F. Curtis 1982. Introduction to Environmental Remote Sensing.

Britain: Fletcher and Son Ltd.

Herlianto. 1986. Urbanisasi dan Pembangunan Kota. Bandung: Alumni.

Ray. M. Northam. 1979. Urban Geography. New York: John Wiley and Sons Inc.

Surna T. Jayadiningrat 1990. Kependudukan dan Lingkungan Hidup, suatu Tinjauan. Jakarta: Kantor Menteri Negara Kependudukan dan Lingkungan Hidup

Sutanto. 1982. Penginderaan Jauh Untuk Penggunaan Lahan Urban. Yogyakarta. Fakultas Geografi.

1982. Penafsiran Foto Udara Untuk Penaksiran Jumlah Penduduk dan Distribusinya. Studi Kasus di Kecamatan Kalianda dan Kecamatan Palas, Kabupaten Lampung Selatan. Desertasi Untuk Memperoleh Derajad Doktor Dalam Ilmu Geografi Pada Universitas Gajah Mada, Yogyakarta

1989. Foto Udara Sebagai Sumber Informasi Untuk Pengembangan Lingkungan Kekotaan di Indonesia. Makalah Untuk Seminar Nasional Mahasiswa yang diselenggarakan oleh Senar Mahasiswa Fakultas Geografi UMS. 